\title{
Läsning för folket? \\ Gunnlaugs saga ormstungu i skandinaviska nyöversättningar: Hur? För vem? Varför?
}

\author{
MARTIN RINGMAR
}

\section{Inledning}

År 2014 publicerades samtliga islänningasagor i dansk, norsk och svensk nyöversättning. Förlaga var den modernortografiska Íslendinga sögur som förlaget Svart á hvítu gav ut i tre band 1987. Denna utgåva hade då redan legat till grund för en engelsk översättning (1997) på förlaget Leifur Eiríksson Publishing, grundat för detta ändamål av Jóhann Sigurðsson från Svart á hvítu. Samme man startade sedan Saga forlag för de skandinaviska utgåvorna, vilka är i fem delar liksom den engelska och i varierande grad återanvänder dess paratexter. Fem år efter utgivandet, i september 2019, ordnades en konferens i Reykjavik som bl.a. skulle summera hur de skandinaviska nyöversättningarna tagits emot, och föreliggande artikel bygger på ett föredrag där. ${ }^{1}$

De skandinaviska utgåvorna är i påkostade band och har omfattande inledande och avslutande förklarande texter: i $S v$ totalt 112 sidor, i $D a$ omkring 130 och i No cirka $80 .^{2}$ Alla tre inleds med en hälsning från

\footnotetext{
1 "De islandske sagaer i en ny udgave på dansk, norsk, svensk og islandsk" (Reykjavik 6-7/9 2019). Saga forlag gav även ut sagorna i original i fembandsformat år 2018, vilket delvis bekostades av Alltinget med anledning av Islands 100 år som suverän nation (https:// stundin.is/blogg/thorbergur-thorsson/ny-utgafa-af-islendingasogunum; läst 29/8 2019).

${ }^{2}$ Förkortningarna $D a$, No och $S v$ syftar dels på de tre utgåvorna generellt, dels, om sidhänvisning finns, på band I i respektive utgåva; Is syftar på förlagan (1987) och Eng på
}

Ringmar, Martin. 2021. Läsning för folket? Gunnlaugs saga ormstungu i skandinaviska nyöversättningar: Hur? För vem? Varför?

Scripta Islandica 72: 107-126.

(C) Martin Ringmar (CC BY)

DOI: $10.33063 /$ diva-439403 
respektive regent, av vilka drottning Margrethe är personligast och bl.a. delger läsarna att "[f]ra en ung alder har sagaerna begejstret mig" (något sådant säger varken Harald eller Carl Gustaf). Totalkostnad för de tre boxarna - i cirka 2000 exemplar var - lär ha varit drygt 15 miljoner svenska kronor (Edlund 2015: 457), något som till stor del bestritts av olika kulturfrämjande institutioner och fonder. Dessutom har Islands regering köpt in hundratals exemplar som skänkts till bibliotek i Norden. ${ }^{3}$

Att förlaget fått kostnaderna täckta av mecenater och att det dessutom är baserat på Island har möjligen haft menlig inverkan på försäljningen utomlands:

Försäljningsmässigt har den svenska översättningen varit ett fiasko. Saga forlag, det isländska förlag, som står bakom projektet har enbart distribuerat böckerna till Sverige genom försäljning via den egna webbplatsen. [...] I Norge och Danmark har försäljningen gått betydligt bättre. Flera av de översättare som arbetade med den svenska utgåvan är mycket missnöjda med att förlaget enbart koncentrerat sig på att få ut verket utan att till synes ha haft några som helst tankar på hur det skulle kunna nå svenska lärare [sic! ]. ${ }^{4}$

Och mycket tyder på att försäljningen gått bättre i grannländerna än i Sverige, inte minst då i Danmark där dessutom ett urval publicerats i två lätthanterligare volymer på Gyldendals 2017-18 (Islændingesagaerne: et udvalg i ny oversættelse). ${ }^{5}$ Det har vidare varit tal om att de skandinaviska nyöversättningarna ska bli fritt tillgängliga digitalt, men när tycks ännu oklart.

Till konferensen 2019 hade jag blivit ombedd att jämföra översättningarna av en kortare saga som innehåller poesi, och valet föll på Gunnlaugs saga ormstungu. Så avsikten är här dels att ge en beskrivning av de skandinaviska utgåvorna generellt, dels att jämföra de tre versionerna av

den engelska utgåvan från 1997. Den svenska utgåvan har utförligt recenserats av LarsErik Edlund $(2015,2017)$.

${ }^{3}$ I Sverige har varje kommunbibliotek fått minst ett av totalt 390 gåvoexemplar (e-brev från Kristinn Jóhannesson 30/9 2019). Saga forlag har dessutom skänkt varje översättare en komplett fembandsbox, även till dem vilka - i likhet med artikelförfattaren - enbart översatt ett par kortare sagor. Rimligtvis har sponsorpengarna bidragit till att möjliggöra denna generositet.

4 https://www.islandsbloggen.com/2018/01/island-skanker-sverige-islanningasagor.html (läst 29/8 2019).

${ }^{5}$ Den danska utgåvans stora genomslag, försäljningsmässigt och medialt, bekräftades av flera föredrag under konferensen i Reykjavik i september 2019. 
Gunnlaugs saga, inbördes och i relation till förlagan, med särskilt fokus på namnskick, ordförråd, tempusbruk och återgivandet av poesin.

\section{1 Översättarna av Gunnlaugs saga}

Av de tre skandinaviska översättarna av Gunnlaugs saga (GS) var den danske, Rolf Stavnem (f. 1965), den mest erfarne med ett 15-tal översatta böcker från isländska, gammal och ny. Han är en av de centrala översättarna inom $D a$ med fem sagor (totalt 367 sidor) och han fungerade dessutom som poesigranskare för hela utgåvan. Den svenske översättaren, Mats Malm (f. 1964), hade enbart tre tidigare översättningar i bagaget - samtliga från fornisländska - men som professor i litteraturvetenskap och numera ledamot i Svenska Akademien besitter han avsevärt kulturellt kapital; han har dessutom kopplingar till $S v$-redaktörerna via Göteborgs universitet. Förutom GS har han översatt ytterligare två sagor i $S v(93 \mathrm{~s}$. totalt). Arnhild Mindrebø (f. 1941) studerade på Island läsåret 1963-64 och arbetade sedan som gymnasielärare i norska och tyska. Trots obetydlig tidigare erfarenhet blev hon uppmanad av sin f.d. elev, No-redaktören Jon Gunnar Jørgensen, att översätta för No vilket resulterade i sju sagor samt sex tåtar eller kortsagor (totalt $322 \mathrm{~s}$.).

\subsection{Generella översättningsstrategier}

De skandinaviska nyöversättningarna är kollektiva projekt. I $D a$ leddes 14 översättare av en redaktör, medan $S v$ :s tre redaktörer styrde hela 24 översättare, och i Norge arbetade totalt 19 översättare under en redaktör för respektive nynorska och bokmål. ${ }^{6}$ Översättarnas insatser varierade naturligtvis, från en enda tåt på några sidor till flera längre sagor; exempelvis står Rolf Stavnem tillsammans med två andra översättare för mer än halva sidantalet i $D a$. Dessutom har i alla tre länderna skönlitterärara författare utan kunskaper i originalspråket fungerat som "kvalificerade läsare" av måltexterna.

Som i alla projekt av det här slaget - man kan jämföra med bibelöversättning - blir slutprodukten i skiftande grad en kompromiss. Den danska redaktören, Annette Lassen, säger sig ha eftersträvat en balans mellan

\footnotetext{
${ }^{6}$ Bokmålsredaktören Jon Gunnar Jørgensen (muntligen 6/9 2019) förstod det som att Saga forlag egentligen hade föredragit enbart bokmål, något som dock hade varit ogörligt givet projektets omfattning och tidsramar (av totalt 40 sagor är 23 på nynorska). Det lär f.ö. vara sällsynt att de två skriftspråken samsas inom samma bokpärmar på detta sätt.
} 
översättarens stilvilja och "en nogenlunde homogen og konsekvent gengivelse af originalteksterne" (Da: L). Lassen är för övrigt den av redaktörerna som utförligast diskuterar typiska problem vid översättning av isländska sagor. Tydliga skillnader finns här mellan redaktionerna, där framförallt $S v$ skiljer ut sig beträffande namn och historiskt presens, medan alla tre divergerar i diktöversättningarna.

\section{Gunnlaugs saga i översättning}

Den första översättningen av Gunnlaugs saga ormstungu kom ut 1775 i Köpenhamn i en parallellspråklig praktutgåva på isländska och latin, vilken då var den första publicerade kompletta översättningen av en islänningasaga överhuvudtaget (Lassen 2014: 58f). Sedan dess har den blivit en av de mest spridda sagorna, något som ingen utgivare försummar att påpeka: "Gunnlaug ormstungas saga är - om översättningar till olika språk medräknas - den isländska bok, som blivit tryckt flest gånger" (Alving 1938: VIII). Enligt databasen Pýðingar íslenskra miðaldabókmennta har den översatts till totalt 25 språk, enbart överträffad av Njáls saga med 26. ${ }^{7}$ Vad gäller antalet utgåvor och upplagor innehar dock troligen GS fortfarande förstaplatsen, säkert mycket tack vare sitt behändiga format (cirka 30 trycksidor).

Den begränsade längden gör GS lämplig som introduktion till genren islänningasagor, vilket ett stort antal skolutgåvor vittnar om, t.ex. Modersmålslärarnas förenings 1930 (och senare) i översättning av Josua Mjöberg. Troligen har även triangeldramat mellan skalderna Gunnlaug och Hrafn och Helga den fagra förmodats intressera "det nu uppväxande släktet" som därur kunnat hämta "livskraft nog att friska upp sig med" (Bååth 1910: 3). GS har dessutom i många länder kommit ut i original med översatt parallelltext eller med rikliga förklaringar, så t.ex. i England:

"Gunnlaugssaga" has an interesting theme presented in a prose style which, while not offering any grave linguistic difficulties, is of high literary merit; and for these reasons the saga is well suited to fulfil the purpose of this book, namely, to provide a simple and useful reading-book for English-speaking students of Old Norse. (Small 1935: 5)

\footnotetext{
${ }^{7}$ https://sagas.landsbokasafn.is/ (sökningen utförd 31/8 2019).
} 
Det finns många äldre översättningar av GS till de skandinaviska språken, av vilka vissa återutgivits moderniserade, liksom ett flertal bearbetningar för barn och ungdom som i Kata Dalströms Nordiska hjältesagor för ungdom från 1889 eller Erik Hjorth Nielsens Gunløg Ormstunga - en billedsaga från 1994, vilken även översatts till svenska. GS har vidare utgjort grundlag för ett par skandinaviska dramatiseringar liksom för en opera (Gunnlögs saga) skriven 1897 av Preben Nodermann, sedermera domkyrkoorganist i Lund. Operan trycktes i samband med ett konsertant framförande 1927 men väntar ännu på sitt sceniska uruppförande (Bengtsson 1988: 33f).

De svenska översättningarna av GS delas naturligt in i tre perioder: 1856-1872 (3 översättningar), 1930-1962 (3) samt 2014 (1). Under 1800-talet anpassades huvudpersonens namn till Gunlög/Gunnlög men från 1930 heter han Gunnlaug. ${ }^{8}$ Att 1900-talsöversättningarna, vilka för övrigt försvenskar namnen, behåller originaldiftongen i titelnamnet kan bero på att kvinnonamnet Gunlög hade vunnit i popularitet efter sekelskiftet 1900. Den danska motsvarigheten (Gunløg) är så gott som okänd som kvinnonamn varför anpassningen av hjältens namn är oproblematisk där. I Norge åter är kvinnonamnet Gunnlaug ungefär lika frekvent som Gunlög i Sverige, men någon differentiering är inte möjlig då norskan behållit diftongen 'au'. På Island är för övrigt mansnamnet Gunnlaugur betydligt vanligare än kvinnonamnet Gunnlaug även om det senare förvisso förekommer.'

\section{De skandinaviska nyöversättningarna}

\subsection{Namnformer}

Isländska egennamn är notoriskt problematiska vid översättning där "diplomatarisk återgivning av källspråkets form utgör den ena ytterligheten, och den andra innebär att alla namnformer byts ut mot ekvivalenter som finns i målspråket" (Hannesdóttir 1998: 70). T.ex. skulle ett namn

${ }^{8}$ Två av 1800-talsöversättningarna samt $S v$ skriver binamnet utan 's' (Ormtunga), de övriga Ormstunga.

${ }^{9}$ Uppgifter om antalet bärare av namnet Gunlög (etc.) har hämtats på: https://www.scb.se; https://www.dst.dk; https://www.ssb.no; https://www.hagstofa.is/talnaefni/ibuar/faeddirog-danir/nofn (sökningarna gjorda 30/8 2019). 
som Puríður rent teoretiskt kunna återges på 33 olika sätt mellan ytterpunkterna Puríður och Turid (Ringmar 2011). I regel har namn anpassats mer i översättningar av fornsagorna än av modern litteratur, vilket bl.a. kan bero på sagaöversättningarnas sekelgamla tradition (tidigare torde även trycktekniska begränsningar ha spelat in). I motsats till $D a / N o$ bryter $S v$ med denna tradition och inför diplomatarisk namnåtergivning, bortsett från att nominativändelsen oftast utelämnas: förlagans Puríður blir Puríð och Pórður blir Pórð (Da/No: Tord) osv. Undantaget är s.k. ija-stammar där ändelsen kvarstår, exempelvis Pórir (Da/No: Tore). Även isländska ortnamn behandlas på samma sätt (t.ex. Borgarfjörður > Borgarfjörð). Såvitt bekant har detta system aldrig använts tidigare vid översättning till svenska av vare sig gammal eller modern isländska. ${ }^{10}$

Saken kompliceras dock av att vissa namn anpassas om de anses äga hävd på svenska (t.ex. Erik blodyx), vilket ibland leder till inkonsekvenser. Jarlen som Gunnlaug besöker i Skara heter Sigurd i $S v$ (men Sigurd i $D a /$ No) medan hans norske kollega försvenskas till Erik (No: Eirik). Den norskfödde grönlandskolonisatören skrivs däremot med diftong och accenttecken i $S v$ : "Eirík den röde". Vidare förekommer namnet Olof i fyra varianter: Olof Skötkonung heter så i GS men Olaf i Hallfreðs saga liksom i namnregistret. Olof Trätälja, som figurerar i bl.a. Egils saga, behåller däremot alltid sitt svenska namn. De norska namnarna heter Olav och islänningarna Ólaf i $S v$. (I $D a / N o$ förekommer enbart formen Olav.)

Enligt redaktörerna står troheten mot originalets namnformer"iöverensstämmelse med modern översättningspraxis" ( $S v$ : xii), ett argument som dock inte i sig bevisar det nya systemets överlägsenhet. Dessutom handlar det som sagt beträffande sagaöversättning snarast om ett brott mot praxis, vilket framgår av en jämförelse mellan svenska översättningar av Njáls saga (se tab. 1).

Lars Lönnrot följde alltså traditionen med anpassade namn i Njals saga från 2006, men när texten publicerades i Sv 2014 tillämpades dennas namnåtergivning.

Vad är avsikten bakom traditionsbrottet i $S v$ ? Möjligen är de islandiserade namnen tänkta att signalera autenticitet och därmed stärka nyöver-

${ }^{10}$ Däremot tycks $S v$ ha fått en efterföljare i översättningen av Bergsveinn Birgissons Den svarte vikingen (2019), med den anmärkningsvärda skillnaden att översättaren John Swedenmark låter kvinnonamnen behålla nominativändelsen, t.ex. Ragnhildur, Sigríður, Puríður osv. i motsats till Guðmund, Ingólf etc. Ett möjligt skäl till detta kan vara att formen Guðmund finns i det isländska paradigmet (i ackusativ) medan kvinnonamnen har ackusativformen Sigríði etc. 
Tab. 1. Några namn i översättningar av Njáls saga.

\begin{tabular}{lllll}
\hline Översättning & Ásgrímr & Hrútr & Mörðr & Práinn \\
\hline A.U. Bååth (1879) & Åsgrim & Rut & Mård & Tråen \\
Hjalmar Alving (1943) & Asgrim & Hrut & Mård & Traen \\
Åke Ohlmarks (1964) & Åsgrim & Hrut & Mård & Tråen \\
Ingegerd Fries (1981) & Asgrim & Hrut & Mård & Traen \\
Lars Lönnrot (2006) & Åsgrim & Hrut & Mård & Tråen \\
Lars Lönnrot (2014) & Ásgrím & Hrút & Mörð & Práin \\
\hline
\end{tabular}

sättningens auktoritet som trogen återgivning av originalet. Namnformerna understryker vidare att originaltexten är skriven just på isländska, inte på "gammal götiska". (Kanske spelar det in här att $S v$ har en islänning som huvudredaktör?) Uttalet försvåras hursomhelst, eftersom det onekligen blir besvärligare för svenskar att diskutera t.ex. Gunnar på Lidarände om han bor på Hlíðarendi. ${ }^{11}$ För att inte tala om Hallfreð vandræðaskáld. Ty även binamnen behåller ofta sin isländska form i $S v$, i motsats till $D a / N o$ och äldre svenska översättningar, vilket leder till en viss förlust i begriplighet; jfr t.ex. "Auðun Festargram" i $S v$ med "Ødun Lænkehund" i $D a$ eller "Audun bandhund" i Alvings och Ohlmarks' svenska översättningar.

\subsection{Historiskt presens}

Att ha enhetlig namnåtergivning i hela utgåvan ter sig rimligt, oavsett vilka principer som valts, men det tycks mindre tvingande att som $S v$ nästan helt avstå från historiskt presens (jfr Edlund 2017: 374f). Da däremot bevarar tempusbyte "i tillempet form" (LIII), vilket innebär att växling i allmänhet tillåts mellan grafiska meningar men inte inom dem. Historiskt presens undviks för övrigt även i den engelska utgåvan (Eng: xv), vilket kanske har påverkat den svenska. ${ }^{12}$ De svenska redaktörerna motiverar sitt beslut bl.a. med att förkortningar i handskrifterna kan göra det svårt att avläsa rätt verbform (t.ex. av anföringsverben meela och segja): ${ }^{13}$

\footnotetext{
${ }^{11}$ Namnformerna motverkar sålunda $S v$-redaktören Karl G. Johanssons förhoppning om "en svensk text som kan läsas högt" (citat i Edlund 2017: 374). Sv innehåller inte heller några uttalsanvisningar, vare sig för modernt eller fornisländskt uttal.

${ }^{12} \mathrm{Om}$ (frånvaron av) historiskt presens i engelska sagaöversättningar - och specifikt i GS - se Durrenberger \& Durrenberger 1992: 51-57.

${ }^{13}$ Lars Lönnroth (1996: 38) gör en poäng av en tempusväxling i Bolles vredesutbrott mot
} 
Tab. 2. Anföringsverb i GS.

\begin{tabular}{lllll}
\hline Presens/preteritum & $I s$ & $D a$ & No & Sv \\
\hline segir/sagði & $91 / 14$ & $25 / 112$ & $80 / 142$ & $7 / 130$ \\
svarar/svaraði & $66 / 2$ & $62 / 7$ & $65 / 2$ & $2 / 63$ \\
maelir/maelti & $0 / 68$ & - & - & - \\
\hline S:a presens/preteritum & $157 / 84$ & $87 / 119$ & $145 / 144$ & $9 / 193$ \\
\hline S:a & 241 & 206 & 289 & 202 \\
\hline
\end{tabular}

Bruket av historiskt presens i moderna utgåvor av isländska sagatexter bygger således ofta på osäker filologisk grund. På grund av detta har de föreliggande översättningarna mestadels avstått från att markera historiskt presens, men också för texthelhetens skull, då denna tidsform i översatt form lätt kan framstå som stilistiskt mer markerad och regelmässig än i källtexterna. $(S v \text { : XIII) })^{14}$

Men det finns mycket annat som står "på osäker filologisk grund" såsom bl.a. interpunktion och kapitel- och styckesindelning. T.ex. delas GS upp i hela 368 stycken i $I s$, vilket i stort sett följs i $\mathrm{Da} / \mathrm{Sv}$ medan $\mathrm{No}$ reducerar dem med mer än hälften (se tabell 3); detta att jämföra med exempelvis utgåvan i serien Íslenzk fornrit där GS indelas i 15 stycken.

I tabell 2 redovisas tempus vid tre anföringsverb, varav framgår hur presens ändrats till preteritum i $S v$.

Det är vidare värt att nämna att det typiska anföringsverbet vid dikter, kveða, används 28 gånger i GS i Is (enbart i preteritum, kvað) och 26 gånger i $\mathrm{Da}$ men inte alls i $S v$. Det förefaller dock osannolikt att verbet kvacde skulle "finnas" i högre grad på danska än kväda på svenska, utan frånvaron illustrerar snarare $S v$ :s vilja att distansera sig från en äldre svensk sagatradition.

Att $N o$ har betydligt fler fall av anföringsverb än $D a / S v$ beror på att de senare i stort sett helt strukit vad som kan kallas "pleonastisk anföring" (se tabell 3): ${ }^{15}$

Gudrun (Laxdalingarnas saga): "Att detta utbrott är något ovanligt och just därför särdeles omskakande markeras till yttermera visso av att berättaren växlar tempus till historiskt presens ('Då säger Bolle')". Lönnroths analys bygger på en tidigare översättning till svenska, men utifrån $S v$ fungerar inte exemplet - "Då sade Bolli" ( $S v$ V: 81) - vad det än sedan står i handskrifterna.

${ }^{14}$ Den sista meningen i citatet är svårtolkad då "markerad" närmast är en motsats till "regelmässig".

${ }^{15}$ All typografisk framhävning i citat är min om inte annat anges. 
Jarl mcelti: "Skúli Porsteinsson," segir hann, "hvað manna er pessi á Íslandi?" (Is: 1174)

Jarlen sa: "Skule Torsteinsson," sa han, "hva slags folk på Island kommer denne mannen fra?" (No: 273)

Jarlen sagde: "Skule Torstenssøn, hvad slags familie på Island stammer han fra?" (Da: 305)

Jarlen sade: "Skúli Porsteinsson, vad är det för människor på Island som han härstammar från?" (Sv: 280)

En skillnad mellan Is och No är emellertid att den förra alltid har två olika verb, vilka dessutom oftast står i olika tempus; den absolut vanligaste kombinationen är maelti i preteritum och segir i presens som i exemplet ovan. Intrycket av (onödig) upprepning blir sålunda starkare i No.

\subsection{Ordförråd}

Beträffande ordförrådet tycks alla redaktionerna vilja begränsa till ett nödvändigt minimum den norröna ordskatt som präglat äldre översättningar (No är dock minst restriktiv). ${ }^{16}$ T.ex. lyser fränder och fränkor helt med sin frånvaro i de tre GS medan släktingarna är desto talrikare. Målet tycks vara en text som varken ska framstå som modern eller gammaldags: "Det har i sagens natur ikke været en målsætning at lade sagaerne fremstå som moderne tekster. [...] Arkaiske ord og vendinger er så vidt muligt undveget" ( $D a$ : L; kursiv i orig.). Beträffande lånord vill dock $D a$ vara "sprogligt inkluderende" och tillåta främmande ord med visst burspråk i danska - exempelvis "økonomi" - medan senare lån undviks: "det går tilsyneladende en grænse her, som de fleste oversættere og læsere ikke $\emptyset$ nsker overskredet" (Da: LII). Engelska lånord är alltså inte okej.

Att policyn skiljer sig åt framgår av GS som på danska har fler latinbaserade lånord än $N o / S v$ :

blev meget aggressiv (Da: 298) svært sint (No: 267); brösta upp sig (Sv: 283)

Vi generer sagesløse folk (Da: 307) går løs på (No: 274); trampar på (Sv: 291)

\footnotetext{
${ }^{16}$ T.ex. översätter Alving ordet vanleikr med "vänhet" (på tal om Helga den fagra) men förklarar i en fotnot att det "närmast [torde] betyda vad vi kalla charm", ett ord som i detta sammanhang "förbjuder sig självt" (1938: 268).
} 
Gunløg takker ham for invitationen (Da: 313)

at han [...] ikke kendte til detaljerne (Da: 313)

Torkel [...] havde inviteret Illuge Sorte (Da: 316)

på græssletten stod folk i en cirkel

(Da: 321) tilbudet (No: 279); erbjudandet ( $S v$ : 297)

men bare uklart (No: 279); inte kände till allt $(S v: 297)$

innbød (No: 281); bjudit (Sv: 299)

ring (No: 286); ring ( $S v: 304)$

Detta modernare ordförråd förekommer även i dikterna i $D a$, möjligen som avsiktliga stilkrockar: "nu har jeg chancen/ til at vise hvorfor" (vers 4); "sprang på mig konstant/ i spyddenes spektakel" (vers 22).

Ett tvärt kast mellan register uppstår i Da/No när det norröna fylgjor står intill lånorden "gravid" respektive "personer":

De fugle må være stormænds fylgjer, og din kone er gravid [...] (299)

Disse fuglene kan være fylgjene til viktige personer. Kona di er med barn [...] (267)

Örnarna och falken måste vara stora mäns fylgjor. Din hustru väntar barn [...] (283)

Exemplet illustrerar också karakteristiskt hur det talspråkligare "er med barn" i No kontrasterar mot det mer neutrala "väntar barn" i $S v$.

\subsection{Ordantal och meningslängd}

Redaktörerna för de olika utgåvorna har beredvilligt gett tillgång till GS digitalt och sålunda har vissa parametrar kunnat undersökas maskinellt, vilket redovisas i tabell 3 .

Som tabell 3 visar har ordantalet ökat påfallande i $\mathrm{Da}$ och $N o$, med omkring 9\%, medan ökningen på knappt 3\% i Sv är förväntad vid källtextnära översättning från isländska (bl.a. därför att obestämd artikel tillkommer). Men $S v$ har å sin sida ökat antalet grafiska meningar avsevärt, vilka då blivit kortare i genomsnitt. Förkortningarna resulterar ibland i en effektfull komprimering, som i följande avsnitt vilket fördelaktigt tål jämförelse med expansionen i $\mathrm{Da} / \mathrm{No}$ :

"Hvar komu feður okkrir pess," segir hann, "að minn faðir væri eftirbátur píns föður, hvar nema alls hvergi? Skal og svo með okkur vera.” (1179; 24 ord) 
Tab. 3. Några variabler i GS (exklusive poesi och paratext).

\begin{tabular}{lllll}
\hline & Is & $D a$ & No & Sv \\
\hline Antal ord & 9598 & 10520 & 10469 & 9861 \\
Ökning \% & - & 9,5 & 9,0 & 2,7 \\
\hline Stycken & 368 & 354 & 127 & 359 \\
\hline Punkt & 590 & 634 & 631 & 713 \\
Kolon $^{\mathrm{a}}$ & 158 & 161 & 157 & 159 \\
Frågetecken & 34 & 34 & 34 & 37 \\
Utropstecken & 0 & $10(!)$ & 0 & 0 \\
\hline S:a grafiska meningar & 782 & 839 & 822 & 909 \\
Ord/grafisk mening & 12,3 & 12,5 & 12,7 & 10,8 \\
\hline Inskjuten (pleonastisk) anföring & 55 & 11 & 55 & 5 \\
\hline Totalt antal eg/jeg/jag & 93 & 112 & 115 & 121 \\
Varav initialt (Eg/Jeg/Jag) & 12 & 35 & 27 & 43 \\
\hline
\end{tabular}

$\underline{\text { Not }}$

a Kolon förekommer nästan uteslutande i anföringskonstruktioner av typen "Gunnlaug sade/svarade:".

"Hvornår er det nogensinde sket for vores fædre, at min far var på slæb hos din far? Det er aldrig nogensinde hændt, og sådan kommer det heller ikke til at blive mellem os." (311; 33 ord)

"Når har det vært slik med fedrene våre", sier han, "at min far diltet etter din far? Aldri har det vært slik, og slik skal det også være med oss.” (277; 30 ord)

"När hängde min far i släptåg efter din far? Aldrig. Detsamma skall gälla oss." (295; 14 ord)

Men strategin med fler och förkortade meningar kan även orsaka en viss monotoni i $S v$ när korta huvudsatser staplas på varandra:

Jafnan skemmtu pau Helga sér að Helga och Gunnlaug brukade roa sig tafli og Gunnlaugur. Lagði hvort med brädspel. De fattade snart tycke peirra góðan pokka til annars för varandra. Detta skulle visa sig bráđlega sem raunir bar á síðan. Pau senare. De var i samma ålder. (285) voru mjög jafnaldrar. (1170)

$S v$ har här fyra jämnlånga huvudsatser (5-8 ord) som alla inleds med 
subjektet, medan originalet har tre huvudsatser av varierande längd $(9,13$ och 4 ord) av vilka en inleds med ett tidsadverbial, en med tomt fundament (s.k. narrativ inversion) och bara den sista med subjektet. ${ }^{17}$ Korta meningar hör för övrigt till de stildrag Tage Danielsson överdriver i sin parodi på isländsk saga (Sigurds saga), som har en genomsnittlig meningslängd på cirka fem ord..$^{18}$ Sigurds saga excellerar även i den för sagastilen typiska topikaliseringen ("Harald dräpte jag. Pris rönte jag därför."), vilken $S v$ snarast underutnyttjar. En genomgång av de två första kapitlen i GS visar att 50\% av huvudsatserna inleds med annat än subjekt i $I s$, mot $30 \%$ i $N o$ och ungefär $25 \%$ i $D a / S v$.

I No tycks ordexpansionen inte minst syfta till att nå ett talspråkligare tonfall:

"Pitt fullting vildi eg hafa til kvonbænar við Porstein Egilsson að biðja Helgu dóttur hans." (1180; 15 ord)

"Jeg ville gjerne ha din hjelp til å dra på frierferd til Torstein Egilsson for å be om Helga, datteren hans." (278; 21 ord)

"Jag vill ha ditt stöd i ett frieri. Jag skall be Porstein Egilsson om hans dotter Helga." (295; 17 ord)

Citatet ovan illustrerar även hur $S v$ typiskt delat en grafisk mening i två vilka båda inleds med samma subjekt, jag (jfr tabell 3).

\subsection{Dikterna}

Den inflikade poesin med versmåttet dróttkvaett hör som bekant till det mest svåröversatta i sagorna, och det finns olika uppfattningar om vad i den som bör bevaras. Att bevara "allt" går inte. Samtliga redaktörer diskuterar problemet:

\footnotetext{
${ }^{17}$ Ett antal läsarreaktioner på GS (Sv) har samlats in, bl.a. följande från en gymnasielärare i svenska (64 år): "Stilen är typisk för isländska sagor, korta och okomplicerade meningar, nästan inga bisatser". Men $S v$ framstår alltså i detta avseende som "isländskare" än originalet: 10,8 ord per grafisk mening mot 12,3 i Is.

${ }^{18}$ Ur Sigurds saga (som blott är 1 sida lång): "En man hette Sigurd. Starkast var han på Island. [...] Harald hette en väldig kämpe. [...] I kämpalek möttes Harald och Sigurd. [...] Sigurd spräckte Haralds skalle. Ihjälslagen låg Harald, den väldige kämpen. [...] Ont tal nådde Sigurd. Sigurd trädde in över Gunnars tröskel. 'Ond tunga är mans bane', talade Sigurd. Sigurd dräpte Gunnar. Ting blev hållet. Sigurd talade: 'Harald dräpte jag. Pris rönte jag därför. Gunnar dräpte jag. Tvåfalt månde jag nu prisas.”" (Danielsson 1964: 89).
} 
[...] oversætterne [er] blevet opfordret til så vidt muligt at bevare kenninger, allitterationer og antallet af stavelser i de enkelte linjer. ( $D a$ : LI)

Vi har valgt å gjengi strofene slik at de blir lett forståelige for en norsk leser. [...] Av og til har vi gjengitt enkle kjenninger, men uten å gå særlig langt i å gjenskape skaldens poetiske språk. (No: XLI)

De här föreliggande översättningarna är således att betrakta som ett slags kompromisser, där de innehållsliga och i någon mån de rytmiska elementen givits företräde. ( $S v \mathrm{~V}: 420)$

Ingen säger sig avse att respektera originaldikternas inrim eller onaturliga ordföljd, vilken senare delvis är en följd av kraven på inrim och allitteration (även om den ökade komplexiteten också kan ha tillskrivits ett värde i sig). ${ }^{19}$

Målsättningen att dikterna ska vara "lett forståelige for en norsk leser" bekräftas av den norska GS, som har kvar färre kenningar än $D a / S v$. Möjligen riskerar dock poesin då att bli lite poänglös eftersom själva sakinnehållet ofta är ganska trivialt. Men No har å andra sidan flest regelrätta allitterationer: av totalt 81 radpar i dróttkvaett är 17 i stort sett korrekt allittererade i $N o$, mot fem var i $D a$ och $S v$, och endast $N o$ har strofer med komplett allitteration (vers 1 och 9). No har dessutom bevarat fler av de i originalet obligatoriska trokéerna i radslut: 149 av 162 (mot 117 i $D a$ och 135 i $S v$ ).

No utelämnar sålunda oftast kenningarna medan de i $D a$ förklaras i en parallell spalt och $S v$ ibland bakar in begriplighet genom explicitering tillsammans med bevarad kenning. I strof 12 exemplifieras de tre strategierna:
[...] så $\phi$ lskibets Njфrun
Du kan ikke lege
Du, ölkarets Njörun,
ej kunne forbinde sårene fra sverdet. bistod mig inte, [ølskibs $>$ drikkehorns $>$ Njørun (281) (299)
(gudinde) $>$ kvinde] (315)

I Sv står vidare originalet originellt nog i direkt anslutning till diktöversättningarna. Syftet är naturligtvis inte att underlätta förståelsen av dikterna, utan troligen återigen att påminna läsarna om att de faktiskt läser en översättning. Kanske fyller originaldikterna också en dekorativ funktion?

\footnotetext{
19 Åke Ohlmarks är förmodligen ensam om att konsekvent ha såväl inrim som regelrätt allitteration i sina diktöversättningar (ofta dock på bekostnad av trokéerna i radslut). Han går även längst i fantasifulla kenningar varför dikterna ibland blir tämligen obegripliga även för högt kompetenta läsare.
} 
Intrycket att $S v$ är något formellare, och möjligen försiktigare, än $D a / N o$ gäller även dikterna. T.ex. i vers 14 där Gunnlaug förbannar Helgas föräldrar för att de åstadkommit den vackra flicka som vållar honom smärta:

Lad trollen tage bondens Djevelen dem hente! mesterværk!
Jeg dem begge unner også alt det verste. (282)
Må de illa lönas för att ha avlat den blida och dömas hårt för dådet. (300)

(Anslaget i $D a$ påminner för övrigt om Ohlmarks' småfräcka version (1963): "Trollen tage den dagens/ trägna drängverk i sängen.")

En intressant skillnad mellan $S v$ å ena sidan och $D a / N o$ å den andra visar sig i strof 20 i GS som är identisk med strof 3 i Kormáks saga. ${ }^{20}$ De två sagorna har olika översättare i alla tre redaktionerna och i både $D a$ och No skiljer sig versionerna åt, här exemplifierat med den senare: ${ }^{21}$

Linpyntet var kvinnen

da hun kom imot meg, et blikk hun mot meg kastet, kvast som haukens var det. (GS; No: 285)
Så bjart den blinket, månen, i brynene hennes, under skinnende lyse panna, så satt hun haukeblikk i meg. (Kormaks saga; No: 144)

I $S v$ däremot är versen identisk i båda sagorna, vilket tyder på en hårdare redaktionell styrning av dikterna.

\section{Sammanfattande diskussion}

I Norge kom GS ut år 1859 som bilaga till tidskriften Folkevennen ("Oversat fra Gammelnorsk af O. Rygh"), och 1872 kom P. A. Gödeckes svenska översättning i skriftserien "Läsning för folket", utgiven av "Sällskapet för nyttiga kunskapers spridande". Uppenbart har GS m.fl. isländska sagor då ansetts som lämplig läsning för folkets breda lager. Vilket osökt ger anledning att återvända till rubrikens frågor rörande de skandinaviska nyöver-

\footnotetext{
${ }^{20}$ Enligt Nordal (1938: XLIII) är Kormákr tvivelsutan diktens upphovsman ("má telja vafalaust, að hún sé eftir Kormák"), men vad detta antagande bygger på framgår inte.

${ }^{21}$ Originalet lyder: "Brámáni skein brúna / brims af ljósum himni / Hristar hörvi glæstrar / haukfránn á mig lauka" (Is II: 1188).
} 
sättningarna: "Hur? För vem? Varför?”. Som flera forskare betonat (t.ex. Reiß \& Vermeer 1991: 96f) är översättning en målstyrd verksamhet, och ett svar på frågan "Hur?” kan antyda för vem en översättning är avsedd. Därför ska här några karakteristiska drag hos de tre utgåvorna/översättningarna rekapituleras, samt - måhända en smula spekulativt - en tänkt målgrupp föreslås.

$D a$ utmärks av omfattande paratexter och är dessutom ensam om att i brödtexten grafiskt markera (med ${ }^{\circ}$ ) de begrepp som tas upp i ordförklaringarna, t.ex. i GS: "væggene i hans obod var styrtet sammen" (298). De rikliga förklararingar i parallellspalt vid dikterna förstärker intrycket av pedagogisk ambition. Vidare verkar den danska GS ta ut svängarna mer än $N o$ och i synnerhet $S v$, vilket visar sig t.ex. i tillagda utropstecken ("Som talt af den braveste mand!"; 320), viss talspråklighet ("Kongen svarer: Det var skidt."; 307), en liberal låneordspolicy som ibland medför stilkrockar, och dessutom i enstaka arkaismer: "Hvad forestiller I Jer, Herre?" (309).22 Den tydliga pedagogiska ambitionen för tankarna till den danska folkhögskolerörelsen, för vilken de isländska sagorna som bekant haft en mycket stor betydelse. Och kanske vänder sig $D a$ framförallt till det uppväxande släktet?

No har något mindre av förklarande paratexter än $D a / S v$, och dikterna är lättillgängligare. Tonfallet i GS är ofta talspråkligt med många partikelverb ("De kom raskt godt ut av det med hverandre"; 277) och vissa feminina a-former: bua, jula, elva, sola etc. (men däremot t.ex.tiden, saken, hånden, natten); possessiva pronomen är oftast efterställda (kona di, datteren din). Vidare förekommer något fler "norrönismer" i No än i Da/Sv: austmann (Sv: norrman), grid, svienes (Da: svenskerne; $S v$ : svenskarnas). Det är en vanlig uppfattning att de isländska fornsagorna, i högre grad än i Danmark och Sverige, fortfarande utgör en integrerad del av det norska kulturarvet och detta skulle kunna förklara den populärare ansatsen. För folket?

$S v$ tycks generellt ha förenhetligats mer redaktionellt än $\mathrm{Da} / \mathrm{No}$, t.ex. i tempusbruket och i dikterna. I GS uppvisar $S v$ en stramare och ordknappare stil än de andra två, och genomgående bruk av bl.a. sade och skall bidrar till en viss formalitet. Ordförrådet är neutralt - såväl latinska som norröna lånord undviks - och meningslängden har förkortats med viss syntaktisk monotoni som följd. Och möjligen är de förkortade

\footnotetext{
${ }^{22}$ Pluralformerna I och Jer (med versal) är översättning av pér/yður som Gunnlaug använder vid tilltal av en kung eller jarl, vilka i sin tur duar honom. No har De/Dem, medan $S v$ en gång översätter med ni/er (290) och sedan alltid du/dig.
} 
meningarna det stilmedel som återstår för att signalera "isländsk saga" efter att $S v$ avhänt sig en äldre traditions arkaismer, tempusbruk och frekventa topikaliseringar? Originalspråkets synlighet i namnformerna och i dikterna tyder eventuellt på en "lärd" målgrupp: För den bildade borgerligheten? (Om någon sådan fortfarande finns?)

Slutligen till frågan "Varför?". Det är en ofta upprepad förhoppning att nyöversättningar ska göra klassiska verk "tillgängliga för nya läsare" och då särskilt för "nya generationer" (jfr Ringmar 2012 ${ }^{23}$ ), en tankefigur som återfinns i de tre regenternas hälsningsord:

Det er mit håb, at sagaerne i denne nye oversættelse vil nå ud til så mange som muligt, så nye generationer kan få samme glæde af sagaerne, som jeg har haft. (Margrethe II)

Ved at islendingesagaene nå foreligger samlet $\mathrm{i}$ en ny norsk oversettelse, kan flere - og nye generasjoner - få glede av dette verdifulle verket. (Harald V)

Det är därför glädjande att den [sagalitteraturen] på nytt görs tillgänglig för oss, och då i ny språklig dräkt. (Carl XVI Gustaf)

Men i detta sammanhang förefaller argumentet svagt. De mer kända sagorna, vilka säkert även fortsättningsvis förblir de mest lästa, är lättillgängliga i äldre översättningar på bibliotek, antikvariskt eller online. Att just den senaste översättningen öppnar texterna för nya generationer är i och för sig tänkbart, men i revideringar av de äldre har många eventuella läshinder undanröjts, och dessutom finns det säkert läsare - även yngre - som efterfrågar den fornnordiska atmosfär som norröna lånord tillsammans med konjunktiv- och pluralformer av verben kan tänkas skänka.

I det inledande citatet från Islandsbloggen kritiseras Saga forlag för att $S v$ inte tillräckligt har kunnat nå "svenska lärare". Den freudianska felskrivningen (?) "lärare" är talande, ty ännu för 50-60 år sedan hade t.ex. gymnasielärare i svenska varit en självklar målgrupp för en utgåva av detta slag. Bland deras nutida kolleger är det förmodligen mycket få som ens känner till $S v$ :s existens. Det är alltså lite som tyder på att Edlunds

\footnotetext{
${ }^{23}$ Det framhålls inte sällan att en nyöversättning nu "äntligen" ger oss tillgång till ett visst verk, som t.ex. i en recension av Kormaks saga (2008): "Kormaks saga har tidigare översatts till svenska av A. U. Bååth [...] och Åke Ohlmarks [...]. Båda översättningarna är föråldrade och är snarast att betrakta som romantiserade tolkningar av originalet. Genom [Ingegerd] Fries professionella och moderna översättning blir Kormaks saga här för första gången tillgänglig för en svensk publik" (Haugen 2011: 106-107). Men vad ska man då säga om Kristjan Hallbergs översättning i $S v$ (2014)? Att den "för andra gången" gör Kormaks saga tillgänglig för en svensk publik?
} 
förhoppning om "en stor läsekrets" (2017: 375) för $S v$ skulle ha infriats, även om en framtida nätpublicering kan ändra på den saken.

Att initiativet till nyöversättningsprojekten, liksom en stor del av finansieringen, kommit från Island är talande. Här sågs fornsagorna länge som en nationell skatt och nästintill heliga skrifter. Berömd - eller snarare beryktad - är den lag från 1941, senare förklarad grundlagsstridig, som gav staten äganderätten till all isländsk litteratur från före 1400, och enligt vilken Halldór Laxness m.fl. dömdes för att ha vanhelgat sagorna med sina modernortografiska och "ovärdiga" utgåvor (Helgason 1998: 13368, 2002; jfr Ringmar 2011).

Så rimligtvis förblir det ur ett isländskt perspektiv viktigt att även nyutgåvor som de skandinaviska får en fysisk utformning som återspeglar islänningasagornas ställning som "de nordiska folkens enda garanterat slitstarka bidrag till den så kallade världslitteraturen" (Henrikson 1981: 15). Inledningsorden med autograf från de tre regenterna i färggrann ornat bidrar till en air av pompa och ståt. Och att de skandinaviska nyöversättningsprojekten samordnats multiplicerar förstås deras genomslag med tre. Det förvånar således inte heller att evenemang kring dem använts för att förgylla Islands ordförandeskap i Nordiska ministerrådet, dels vid ovannämnda konferens i september 2019, dels - och framförallt - i juni 2014 när de tre boxarna släpptes under festliga former i kongresscentret Harpa i Reykjavik. I dubbel bemärkelse tungt vägande litteratur.

\section{Referenser}

\section{Primärmaterial}

$D a=$ Islændingesagaerne I-V. Samtlige sagaer og niogfyrre totter. Utg. av A.

Lassen. 2014. Reykjavík: Saga forlag.

Eng = The complete sagas of Icelanders I-V. Including 49 tales. Utg. av V. Hreinsson \& R. Cook. 1997. Reykjavík: Leifur Eiríksson Publishing,

Is = Íslendinga sögur og pættir I-III. Utg. av B. Halldórsson \& al. 1987. Reykjavík:

Svart á hvítu.

No = Islendingesagaene I-V. Samtlige sagaer og førtini tætter. Utg. av J. G.

Jørgensen \& J. R. Hagland. 2014. Reykjavík: Saga forlag.

$S v$ = Islänningasagorna I-V. Samtliga släktsagor och fyrtionio tåtar. Utg. av K.

Jóhannesson, G. D. Hansson \& K. G. Johansson. 2014. Reykjavík: Saga forlag. 


\section{Övriga referenser}

Alvin, Hjalmar, 1938: Förord. I: Egil Skallagrimssons saga och Gunnlaug Ormstungas saga. Isländska sagor, band 3. Stockholm: Bonniers.

Bengtsson, Nils Otto, 1988: Preben Nodermann - legend i Lund. (Gamla Lund: Årsskrift 70.)

Birgisson, Bergsveinn, 2019: Den svarte vikingen. Översättning John Swedenmark. Stockholm: Bazar,

Bååth, A. U., 1910: Sagan om Gunnlög Ormtunga och andra sagor. 2., genomsedda uppl. Stockholm.

Danielsson, Tage, 1964: Sagor för barn över 18 år. Stockholm: Wahlström \& Widstrand.

De isländska sagorna, 1963: Översättning Åke Ohlmarks. Band 2: Västlandssagor. Stockholm: Steinviks.

De isländska sagorna, 1964: Översättning Åke Ohlmarks. Band 5: Sagorna från Öst- och Sydisland. Stockholm: Steinviks.

Durrenberger, E. Paul \& Dorothy Durrenberger, 1992: The Saga of Gunnlaugur Snake's Tongue. With an Essay on the Structure and Translation of the Saga. Rutherford etc.: Associated University Press.

Edlund, Lars-Erik, 2015: Islänningasagorna i nyöversättning - ett nordiskt storverk. I: Nordisk tidskrift (häfte 4). S. 457-470.

Edlund, Lars-Erik, 2017: Recension av Islänningasagorna I-V. Samtliga släktsagor och fyrtionio tåtar. I: Scripta Islandica (vol. 68). S. 369-375.

Hannesdóttir, Anna Helga, 1998: Skimmer, chimärer och chimairor. I: Form innehåll - effekt. Stilistiska och retoriska studier tillägnade Peter Cassirer på 65-årsdagen. Utg. av A. Lundqvist \& al. Göteborg: Institutionen för svenska språket, Göteborgs universitet. S. 67-78.

Haugen, Susanne, 2011: Recension av Kormaks saga. Scripta Islandica. S. 105107.

Helgason, Jón Karl, 1998: Hetjan og höfundurinn. Brotúríslenskri menningarsögu. Reykjavík: Heimskringla.

Helgason, Jón Karl, 2002: Alpingi, fornritin og tuttugasta öldin. I: Handritin. Ritgerðir um íslensk miðaldahandrit, sögu peirra og áhrif. Utg. av Gísli Sigurðsson \& Vésteinn Ólason. Reykjavík: Stofnun Árna Magnússonar. S 145-155.

Henriksson, Alf, 1981: Isländsk historia. Stockholm: Bonniers.

Isländska sagor, 1943: Översatta från fornisländskan och utgivna av Hjalmar Alving. Band 4: Njals saga. Stockholm: Bonniers.

Lassen, Annette, 2014: N. M. Petersens sagaoversættelser. I: Filologen N. M. Petersen - grundlægger og fornyer. Utg. av Frans Gregersen \& al. København: Selskab for Nordisk Filologi. S. 57-80.

Lönnroth, Lars, 1996: Skaldemjödet i berget. Essayer om fornisländsk ordkonst och dess återanvändning i nutiden. Stockholm: Atlantis.

Nials saga, 1879: Från fornisländskan af A. U. Bååth. Stockholm: Seligmann. 
Njals saga, 1981: Översättning Ingegerd Fries. Höganäs: Läsabra.

Njals saga, 2006: Översättning och inledning av Lars Lönnroth. Stockholm: Atlantis.

Nordal, Sigurður, 1938: Formáli. I: Borgfirðinga sǫgur. Íslenzk fornrit III. Reykjavík: Hið íslenzka fornritafélag.

Reiß, Katharina \& Hans J. Vermeer, 1991: Grundlegung einer allgemeinen Translationstheorie. 2. Auflage. Tübingen: Niemeyer.

Ringmar, Martin, 2011: Tecken som gör skillnad! Interpunktion och grafisk struktur i de nordiska översättningarna av Salka Valka. I: Transformationer. Valda texter från IASS 28:e konferens i Lund 2010. Utg. av P. E. Ljung. Köpenhamn/Lund: Centre for Scandinavian Studies. S. 337-347.

Ringmar, Martin, 2012: ”... anses vara mycket god.” Hur åsikter om (ny)översättningar uppstår och sprids: Exemplet Laxness. I: Aspekter av litterär nyöversättning - Aspects de la retraduction littéraire. Utg. av O. Eriksson. Växjö: Linnaeus University Press. S. 165-181.

Small, L. M, 1935: Preface. I: Gunnlaugssaga ormstungu. Leeds School of English Language. (Texts and monographs: Number 1.)

\section{Summary}

In 2014 were published translations of the complete Íslendingasögur into Danish $(\mathrm{Da})$, Norwegian $(\mathrm{No})$, and Swedish $(\mathrm{Sw})$, each in five volumes with comprehensive paratexts. Involving some 60 translators and editors, this is presumably one of the biggest retranslation projects ever in Scandinavia and it has received substantial financial support in each country, respectively, as well as from Iceland. The initiative emanated with an Icelandic publisher, whose 1987 Icelandic edition of the sagas - with modernized spelling - served as a source text (Ice). However, having an Iceland-based publisher may have hampered the access to mainland Scandinavian markets and especially in Sweden sales have reportedly been poor.

Like all translations of sagas, the triplet had to face classical problems like the rendering of proper names, the narrative shifts between past and present tense, and the interspersed Scaldic poetry. As for names, $S w$ abandons the time-honoured tradition of adaptation and maintains their original forms including diacritics, save that the nominative ending -ur is omitted, e.g. Pórður > Pórð (Da/No: Tord). Sw also treads an original path in poetry translation by printing the original Icelandic stanzas in a parallel column. No, in contrast, opts for comprehensibility and simplifies most of the poetic kenningar, whereas $D a$ preserves them accompanied by extensive explanations. Concerning Norse loanwords - once the hallmark of saga translation - all three editions use them restrictively, and $D a$ even admits more Latin-based loanwords than has been customary in this genre.

As for the three versions of Gunnlaugs saga ormstungu (GS), $D a$ and $N o$ tend 
to verbosity with app. $9 \%$ more words than Ice (in contrast to $+3 \%$ in $\mathrm{Sw}$ ), and especially in No this serves to enhance a certain colloquial tone. $S w$, on the other hand, shortens and simplifies sentences by favouring main clauses with subject first, thus at times running the risk of syntactic monotony. It is furthermore suggested here, tentatively, that the differences in the three GS can be explained by different aims (and target groups?): A popular approach in No, a pedagogical zeal in $D a$, and a learned leaning in $S w$.

Keywords: Gunnlaugs saga, sagaöversättning, nyöversättningar

Martin Ringmar

Lunds universitet

Språk-och litteraturcentrum/Nordiska språk

Box 201, SE-22101 Lund, Sverige

Martin.Ringmar@nordlund.lu.se 